\title{
ELECTROPHORETIC PROTEIN PATTERNS AND NUMERICAL ANALYSIS OF Candida albicans FROM THE ORAL CAVITIES OF HEALTHY CHILDREN
}

\author{
Marcelo Fabiano Gomes BORIOLLO(1), Edvaldo Antonio Ribeiro ROSA(2), Wagner Luis de Carvalho BERNARDO(1), Reginaldo Bruno GONÇALVES(1) \& \\ José Francisco HÖFLING(1)
}

\begin{abstract}
SUMMARY
The aim of this research was to evaluate the protein polymorphism degree among seventy-five $C$. albicans strains from healthy children oral cavities of five socioeconomic categories from eight schools (private and public) in Piracicaba city, São Paulo State, in order to identify C. albicans subspecies and their similarities in infantile population groups and to establish their possible dissemination route. Cell cultures were grown in YEPD medium, collected by centrifugation, and washed with cold saline solution. The whole-cell proteins were extracted by cell disruption, using glass beads and submitted to SDS-PAGE technique. After electrophoresis, the protein bands were stained with Coomassie-blue and analyzed by statistics package NTSYS-pc version 1.70 software. Similarity matrix and dendrogram were generated by using the Dice similarity coefficient and UPGMA algorithm, respectively, which made it possible to evaluate the similarity or intra-specific polymorphism degrees, based on whole-cell protein fingerprinting of $C$. albicans oral isolates. A total of 13 major phenons (clusters) were analyzed, according to their homogeneous (socioeconomic category and/or same school) and heterogeneous (distinct socioeconomic categories and/or schools) characteristics. Regarding to the social epidemiological aspect, the cluster composition showed higher similarities $\left(0.788<S_{D} \leq 1.0\right)$ among C. albicans strains isolated from healthy children independent of their socioeconomic bases (high, medium, or low). Isolates of high similarity were not found in oral cavities from healthy children of social stratum A and D, B and D, or C and E. This may be explained by an absence of a dissemination route among these children. Geographically, some healthy children among identical and different schools (private and public) also are carriers of similar strains but such similarity was not found among other isolates from children from certain schools. These data may reflect a restricted dissemination route of these microorganisms in some groups of healthy scholars, which may be dependent of either socioeconomic categories or geographic site of each child. In contrast to the higher similarity, the lower similarity or higher polymorphism degree $\left(0.499 \leq S_{D}<0.788\right)$ of protein profiles was shown in $23(30.6 \%)$ C. albicans oral isolates. Considering the social epidemiological aspect, $42.1 \%, 41.7 \%, 26.6 \%, 23.5 \%$, and $16.7 \%$ were isolates from children concerning to socioeconomic categories A, D, C, B, and E, respectively, and geographically, 63.6\%, 50\%, 33.3\%, 33.3\%, 30\%, 25\%, and 14.3\% were isolates from children from schools LAE (Liceu Colégio Albert Einstein), MA (E.E.P.S.G. "Prof. Elias de Melo Ayres"), CS (E.E.P.G. "Prof. Carlos Sodero"), AV (Alphaville), HF (E.E.P.S.G. "Honorato Faustino), FMC (E.E.P.G. "Prof. Francisco Mariano da Costa"), and MEP (E.E.P.S.G. "Prof. Manasses Ephraim Pereira), respectively. Such results suggest a higher protein polymorphism degree among some strains isolated from healthy children independent of their socioeconomic strata or geographic sites. Complementary studies, involving healthy students and their families, teachers, servants, hygiene and nutritional habits must be done in order to establish the sources of such colonization patterns in population groups of healthy children. The whole-cell protein profile obtained by SDS-PAGE associated with computer-assisted numerical analysis may provide additional criteria for the taxonomic and epidemiological studies of C. albicans.
\end{abstract}

KEYWORDS: Numerical analysis; SDS-PAGE; C. albicans; Healthy children; Oral cavity.

\section{INTRODUCTION}

Different types of electrophoretic techniques have been used for the characterization or typing of Candida species including separation of chromosomes, DNA fragments, isoenzymes, cell-wall glycoproteins and whole-cell proteins $s^{4,7,8,27,28,32,45,49}$. Regarding whole-cell proteins, their separation has been employed satisfactorily in the characterization of bacteria and yeasts ${ }^{12,21,23,56,57,58,59}$. The resulting electrophoretic profiles can be plotted into a binary value matrix that, with computer-assisted support, produces comparative results expressed as similarity or cophenetic correlation matrixes and phenograms ${ }^{24}$. Several investigators employed electrophoretic analysis of whole-cell proteins in the fungi

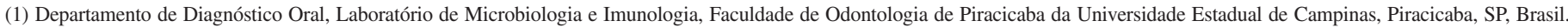
(2) Centro de Ciências Biológicas e da Saúde da Pontifícia Universidade Católica do Paraná, Curitiba, PR, Brasil.

Correspondence to: Marcelo F.G. Boriollo, Av. Limeira 901, Bairro Areião, CP 052, 13414-903 Piracicaba, SP, Brasil. Phone: 55 (19) 3412-5321, e-mail: pgmicro@ fop.unicamp.br 


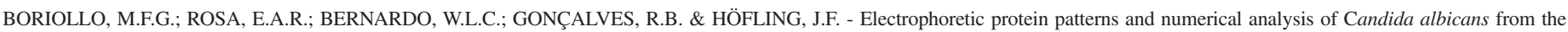
oral cavities of healthy children. Rev. Inst. Med. trop. S. Paulo, 45(5):249-257, 2003.

taxonomy ${ }^{18,20,48,59}$. In addition, variations in this technique made it possible to analyze the intra- and inter-specific variability of Candida species. Radiolabeling proteins with $\left[{ }^{35} \mathrm{~S}\right]$ methionine were used satisfactorily in the differential identification of Candida species and other yeasts ${ }^{49}$. The polyacrylamide gel electrophoresis (SDS-PAGE) also has been used in the identification of oral yeasts. This technique showed high specificity in addition to the rapid acquisition of significant data for classification ${ }^{28}$. In several cases, unidimensional electropherograms of whole-cell proteins and DNA-DNA hybridization data were equalized as their discriminatory capacities $^{9,22,23,24,35}$. Bacterial strains with $90-100 \%$ of similarity in DNA sequences generally have identical protein patterns, while those with at least $70 \%$ of similarity in DNA sequences have similar protein profiles. Such observations showed to be the major pillars on which the application of protein electrophoresis in microbes was based. Moreover, the comparison of electrophoretic protein patterns has been considered a technique having satisfactory taxonomic resolution, which may be applicable to the level of species, subspecies and biotypes ${ }^{24}$. The aim of the present investigation was the evaluation of the protein patterns and numerical analysis of $C$. albicans strains from healthy children oral cavities according to their socioeconomic base and/or school in order to establish their similarities and possible dissemination routes.

\section{MATERIALS AND METHODS}

Yeast isolation. A total of seventy-five $C$. albicans isolates from the oral cavities (saliva) of seventy-five healthy students (6-8 year-old), living in Piracicaba city, São Paulo State, Brazil, having a socioeconomic category (A, B, C, D, or E) and/or from schools (AV, CS, FE, FMC, HF, LAE, MA, or MEP) ${ }^{33}$ were studied. These isolates were identified by morphological criteria by germ tube test, chlamydospore test, growth in chromogenic medium CHROMagar Candida ${ }^{34}$, and associated to carbohydrate assimilation and fermentation tests ${ }^{33,44}$ (Table 1).

Cell cultivation and whole-cell protein extraction. All strains were grown in $50 \mathrm{~mL}$ of YEPD medium ( $2 \%$ dextrose, $2 \%$ peptone, $1 \%$ yeast extract) in a shaker table at $150 \mathrm{rpm}$, at $30^{\circ} \mathrm{C}$, overnight (late log phase - approx $10^{8}$ cells $\left./ \mathrm{mL}\right)^{4,8}$. After growth, the cells were harvested by centrifugation at 3,000 $\mathrm{g}$ for $5 \mathrm{~min}$, and the pellets were washed three times in cold sterile $0.9 \% \mathrm{NaCl}$ in order to remove either culture medium traces or extra-cellular metabolites ${ }^{60,61}$. The last washed pellets were transferred to micro-centrifuge tubes $(2 \mathrm{~mL})$ plus glass beads $(\mathrm{v} / \mathrm{v})$ and $500 \mu \mathrm{L}$ of cold sterile water were added ${ }^{3,40}$. Cells were lysed using a Mini-Bead Beater cell disrupter (Biospec Products, Inc.) at 4,200 rpm, repeating four times of $30 \mathrm{sec}$ each, at 5 min intervals, and placed in an ice bath ${ }^{3,40}$. After cell disruption, tubes were centrifuged at $10,000 \mathrm{~g}$ for $5 \mathrm{~min}$, and the supernatant protein concentration was determined, according to BRADFORD $(1976)^{6,15}$ and adjusted to $1.6 \mu \mathrm{g} . \mu \mathrm{L}^{-12}$. Equal volumes of supernatant and loading buffer ( $5 \mathrm{mM}$ Tris, $2.5 \% 2$ mercaptoethanol, $1.5 \%$ SDS, $0.025 \%$ bromophenol blue, $15 \%$ glycerol) were mixed and heated in a boiling water bath for $10 \mathrm{~min}^{7}$.

Polyacrylamide gel electrophoresis (PAGE). SDS-PAGE protein profiles were obtained after electrophoresis of $50 \mu \mathrm{L}$ of denatured protein solution in polyacrylamide slab gels ${ }^{56}$ with SDS (sodium dodecylsulfate) in a discontinuous buffer system ${ }^{25}$ with $4.5 \%$ stacking gel and $12.5 \%$ running gel. The electrophoresis was performed at 125 volts in a cold chamber and the protein bands present in the gels were fixed in a solution of $12.5 \%$ sulfosalicylic acid for $20 \mathrm{~min}$ and stained with $0.025 \%$
Table 1

Relation of C. albicans samples collected from the oral cavities of healthy students having a socioeconomic base

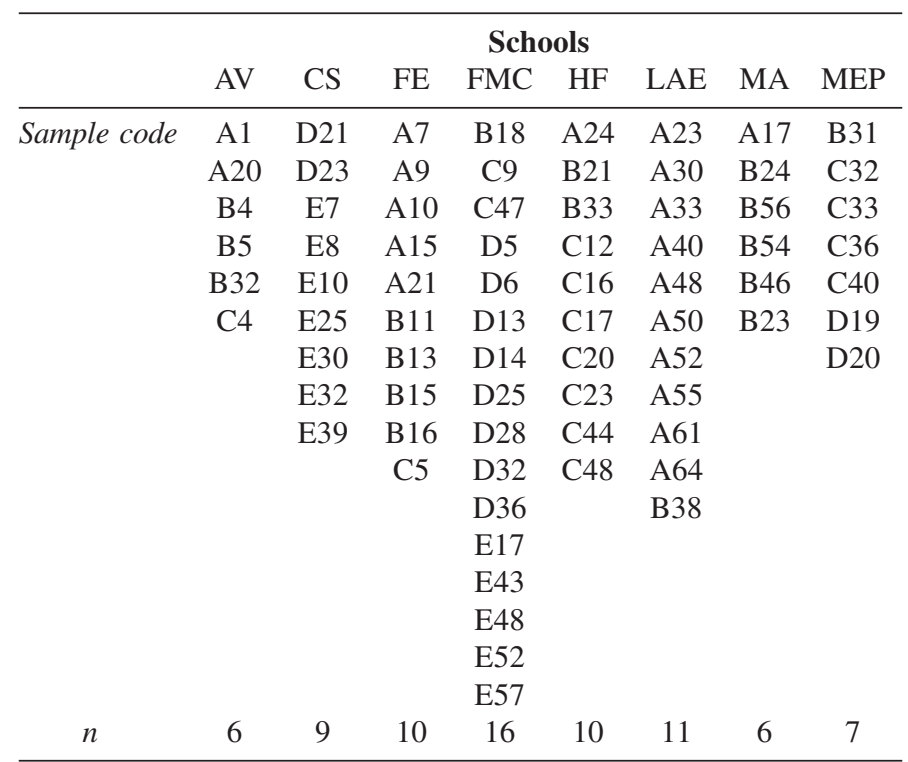

$n$ corresponds to the number of isolates in students population (one isolate per each healthy student). The letters A, B, C, D, and E correspond to isolates deriving from healthy students classified in socioeconomic categories A (19 isolates), B (17 isolates), C (15 isolates), D (12 isolates), and E (12 isolates), respectively. The abbreviations AV, CS, FE, FMC, HF, LAE, MA, and MEP correspond to the schools Alphaville (private), E.E.P.G. "Prof. Carlos Sodero" (public), E.E.P.G. "Profa. Francisca Elisa" (public), E.E.P.G. "Prof. Francisco Mariano da Costa" (public), E.E.P.S.G. "Prof. Honorato Faustino" (public), Liceu Colégio Albert Einstein (private), E.E.P.S.G. "Prof. Elias de Melo Ayres" (public), and E.E.P.S.G. "Prof. Manasses Ephraim Pereira" (public), respectively.

Coomassie Blue G-250 for $12 \mathrm{~h}$. The gels were destained by successive washings in acetic acid:methanol:water (1:2.5:6.5) solution ${ }^{1}$.

Numerical analysis. The images of the gels were captured using an HP 4C scanner (Hewlett Packard Co.) and the relative mobility (Rm values and/or molecular weights) of each protein band was determined by SigmaGel software (Jandel Co.). Matches and mismatches among the bands (originated from presence/absence of protein bands) had the representations 1 and 0 , respectively, considering a confidence interval of $\pm 1.245^{5}$. These data made it possible to construct a binary value matrix that was analyzed using the statistics package NTSYS-pc version 1.70 (Applied Biostatistics, Inc.). The Dice similarity coefficient (1945), $S_{D}=2 \mathrm{a} /(2 \mathrm{a}+\mathrm{u})=2 \mathrm{a} /(2 \mathrm{a}+\mathrm{b}+\mathrm{c})$, was used to obtain the matrix of similarity $\left(S_{D}\right)^{14}$. Dendrogram, represented by non-rooted trees, based on $S_{D}$ values was generated by the unweighted pair-group arithmetic average (UPGMA) clustering method ${ }^{16,50,51}$. Matrix of cophenetic values $\left(S_{C}\right)$ was derived from the UPGMA dendrogram and the Pearson productmoment correlation coefficient $\left(r_{C S}\right)$,

$$
r_{k i}=\frac{s_{k i}}{\sqrt{s_{k}^{2} s_{i}^{2}}}=\frac{\sum_{j=1}^{p}\left(y_{i j}-\bar{y}_{i}\right)\left(y_{k j}-\bar{y}_{k}\right)}{\sqrt{\sum_{j=1}^{p}\left(y_{i j}-\bar{y}_{i}\right)^{2}} \sqrt{\sum_{j=1}^{p}\left(y_{k j}-\bar{y}_{k}\right)^{2}}},
$$

was then computed between the elements $S_{\mathrm{ij}}$ of the original similarity matrix 


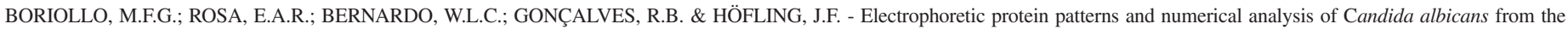
oral cavities of healthy children. Rev. Inst. Med. trop. S. Paulo, 45(5):249-257, 2003.

$\left(S_{D}\right)$ and cophenetic values $C_{\mathrm{jk}}$ of the matrix $S_{C}{ }^{16,23,26,51,53,54}$. The type-strain of $C$. albicans CBS562 (Centralbureau voor Schimmelcultures, Delft, The Netherlands) and molecular weight markers (Bovine Serum Albumin 66,000 Da, Bovine Pancreas Trypsinogen 24,000 Da, Bovine Milk $\beta$ Lactoglobulin 18,400 Da - Sigma-Aldrich Co.) were included in this experiment, in order to establish the degree of similarity among the $C$. albicans strains and to determine reproducibility ${ }^{7,12,13,59}$.

\section{RESULTS}

Reproducibility. The strain protein profiles on different gels were reproducible after three repetitions of each electrophoretic running. Protein extracts of $C$. albicans CBS562 and molecular weight markers were applied in all gels, providing mean value $S_{D}=0.897$.
Strain clustering. The electrophoretic whole-cell protein patterns of $C$. albicans made possible the observation of 20 major bands per lane, within a molecular range weight varying between $18,400 \mathrm{Da}$ and $66,000 \mathrm{Da}$ (Fig. 1). The application of UPGMA clustering method made it possible to build a similarity dendrogram (Fig. 2), in which thirteen major clusters (13 of the 36 78.8-phenons) may be distinguished with $0.788^{78.8 \%}<S_{D} \leq 1.0^{100 \%}$. These clusters have the following compositions:

Cluster 1 (78.8-phenon I): 4 (5.3\%) isolates (D19 ${ }^{\mathrm{MEP}}, \mathrm{E} 32^{\mathrm{CS}}, \mathrm{E} 39^{\mathrm{CS}}$, and $\mathrm{E} 43^{\mathrm{FMC}}$ ) with $0.788<S_{D}<1.0$. Their composition was heterogeneous in regards to both schools (CS, FMC, and MEP) and socioeconomic categories (D and $\mathrm{E}$ ).

Cluster 2 (78.8-phenon II): $4(5.3 \%)$ isolates (E8 ${ }^{\mathrm{cs}}, \mathrm{E} 10^{\mathrm{cs}}, \mathrm{E} 25^{\mathrm{cs}}$,
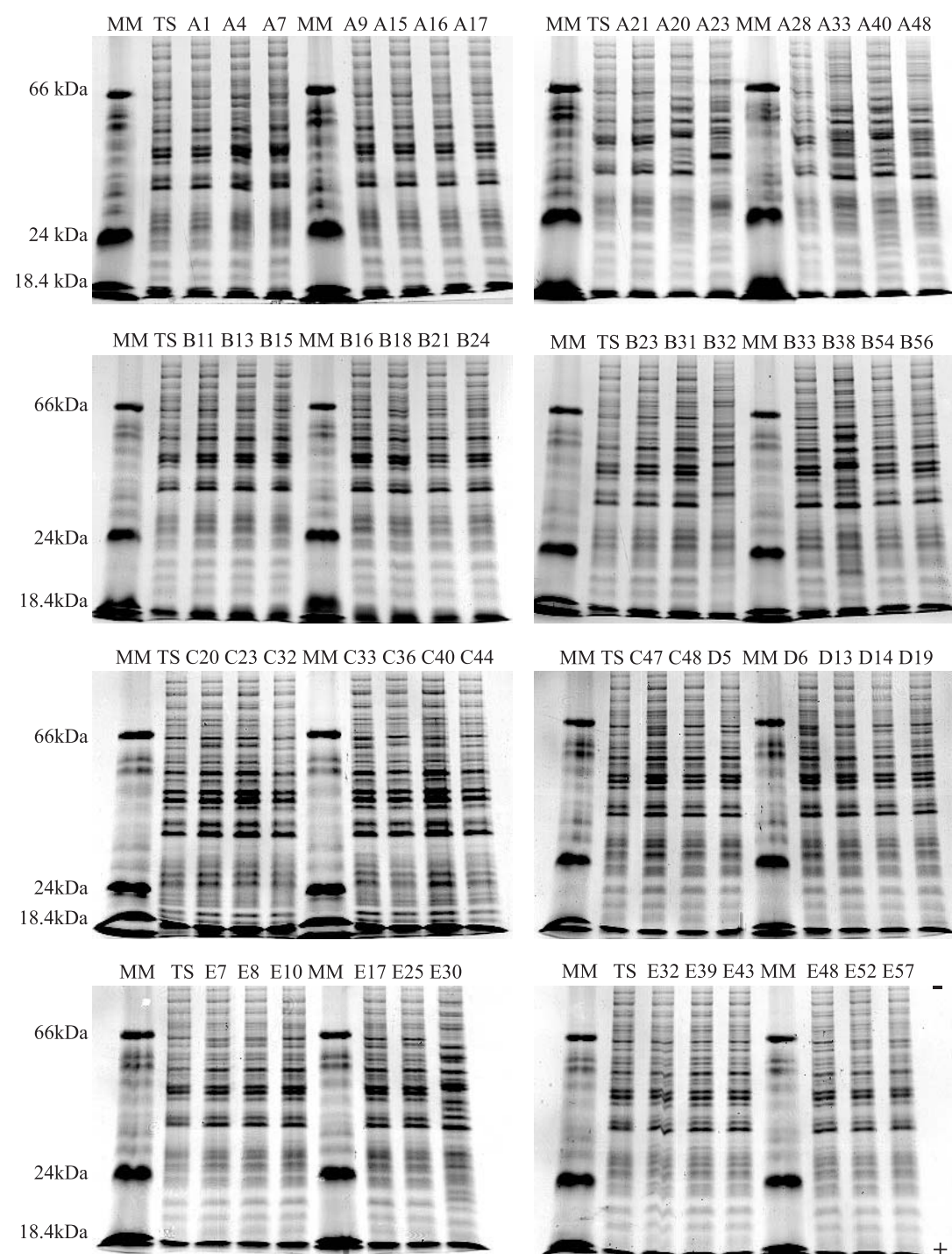

MM TS C47 C48 D5 MM D6 D13 D14 D19
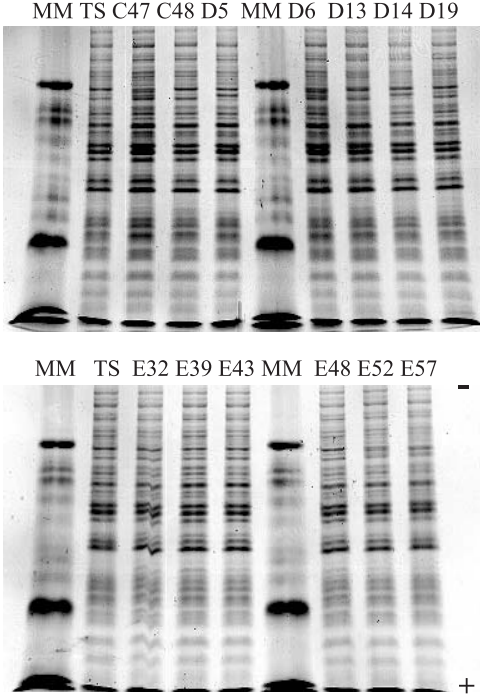
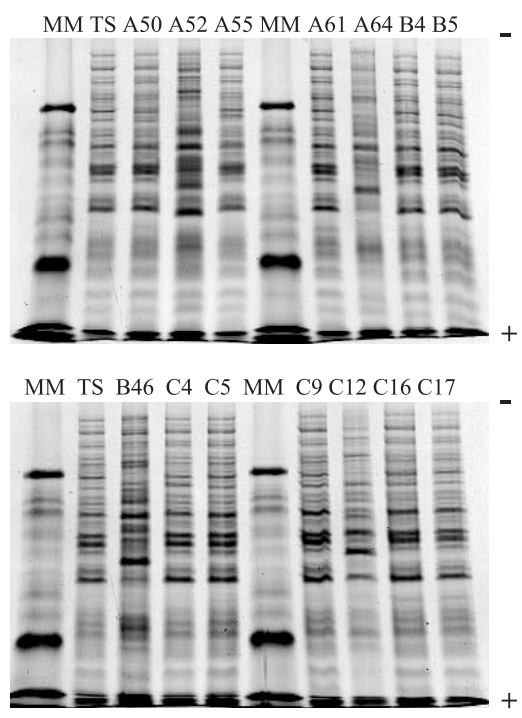

MM TS D20 D21 D23 MM D25 D28 D32 D36

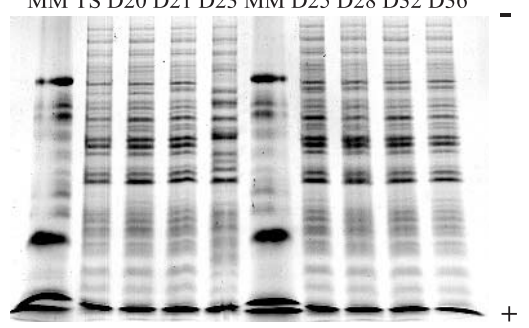

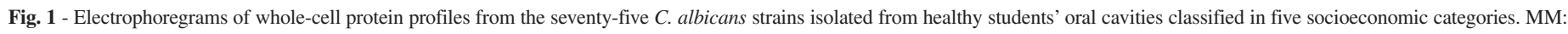

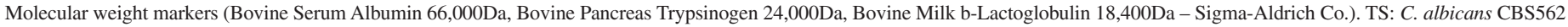
(type-strain). 


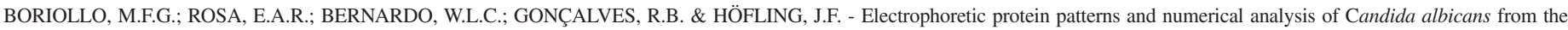
oral cavities of healthy children. Rev. Inst. Med. trop. S. Paulo, 45(5):249-257, 2003.

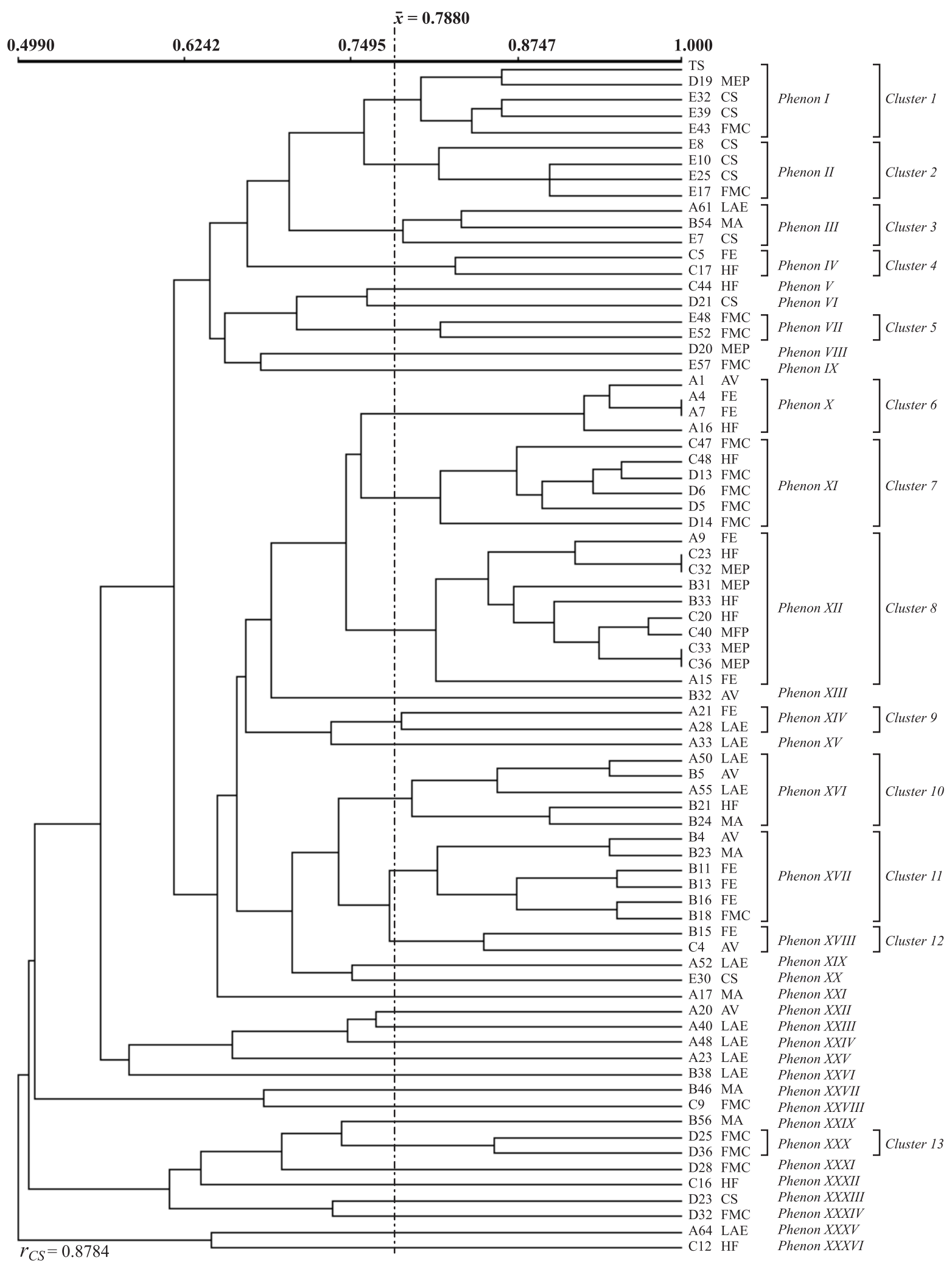

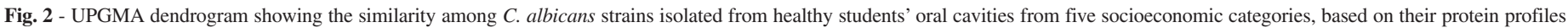
obtained by SDS-PAGE. 


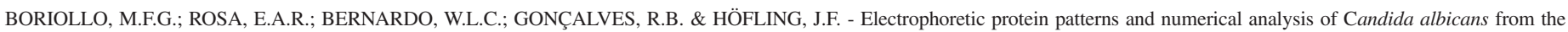
oral cavities of healthy children. Rev. Inst. Med. trop. S. Paulo, 45(5):249-257, 2003.

and $\mathrm{E} 17^{\mathrm{FMC}}$ ) with $0.788<S_{D}<1.0$. Their composition was heterogeneous and homogeneous in regards to schools (CS and FMC) and socioeconomic category $(\mathrm{E})$, respectively.

Cluster 3 (78.8-phenon III): 3 (4\%) isolates (A61 ${ }^{\mathrm{LAE}}$, B54 ${ }^{\mathrm{MA}}$, and E7 ${ }^{\mathrm{CS}}$ ) with $0.788<S_{D}<1.0$. Their composition was heterogeneous in regards to both schools (CS, LAE, and MA) and socioeconomic categories (A, B, and E).

Cluster 4 (78.8-phenon IV): $2(2.7 \%)$ isolates ( $\mathrm{C}^{\mathrm{FE}}$ and $\left.\mathrm{C} 17^{\mathrm{HF}}\right)$ with $0.788<S_{D}<1.0$. Their composition was heterogeneous and homogeneous in regards to schools (FE and HF) and socioeconomic category $(\mathrm{C})$, respectively.

Cluster 5 (78.8-phenon VII): 2 (2.7\%) isolates (E48 ${ }^{\mathrm{FMC}}$ and $\mathrm{E} 52^{\mathrm{FMC}}$ ) with $0.788<S_{D}<1.0$. Their composition was homogeneous in regards to both school (FMC) and socioeconomic category (E).

Cluster 6 (78.8-phenon X): $4(5.3 \%)$ isolates $\left(\mathrm{A} 1^{\mathrm{AV}}, \mathrm{A} 4^{\mathrm{FE}}, \mathrm{A} 7^{\mathrm{FE}}\right.$, and $\mathrm{A} 16^{\mathrm{HF}}$ ) with $0.788<S_{D} \leq 1.0$. Their composition was heterogeneous and homogeneous in regards to schools (AV, FE, and HF) and socioeconomic category (A), respectively.

Cluster 7 (78.8-phenon XI): $6(8 \%)$ isolates $\left(\mathrm{C} 47^{\mathrm{FMC}}, \mathrm{C} 48^{\mathrm{HF}}, \mathrm{D} 13^{\mathrm{FMC}}\right.$, $\mathrm{D}^{\mathrm{FMC}}{ }^{\mathrm{FM}}$ D5 ${ }^{\mathrm{FMC}}$, and $\mathrm{D} 14^{\mathrm{FMC}}$ ) with $0.788<S_{D}<1.0$. Their composition was heterogeneous in regards to both schools (HF and FMC) and socioeconomic categories (C and D).

Cluster 8 (78.8-phenon XII): $10(13.3 \%)$ isolates (A9 ${ }^{\mathrm{FE}}, \mathrm{C} 23^{\mathrm{HF}}$, $\mathrm{C} 32^{\mathrm{MEP}}, \mathrm{B} 31^{\mathrm{MEP}}, \mathrm{B} 33^{\mathrm{HF}}, \mathrm{C} 20^{\mathrm{HF}}, \mathrm{C} 40^{\mathrm{MEP}}, \mathrm{C} 33^{\mathrm{MEP}}, \mathrm{C} 36^{\mathrm{MEP}}$ and $\mathrm{A} 15^{\mathrm{FE}}$ ) with $0.788<S_{D} \leq 1.0$. Their composition was heterogeneous in regards to both schools (FE, HF, and MEP) and socioeconomic categories (A, B, and C).

Cluster 9 (78.8-phenon XIV): $2(2.7 \%)$ isolates (A2 $1^{\mathrm{FE}}$ and $\left.\mathrm{A} 28^{\mathrm{LAE}}\right)$ with $0.788<S_{D}<1.0$. Their composition was heterogeneous and homogeneous in regards to schools (FE and LAE) and socioeconomic category (A), respectively.

Cluster 10 (78.8-phenon XVI): $5(6.7 \%)$ isolates (A50 ${ }^{\mathrm{LAE}}, \mathrm{B} 5^{\mathrm{AV}}$, $\mathrm{A} 55^{\mathrm{LAE}}, \mathrm{B} 21^{\mathrm{HF}}$, and $\mathrm{B} 24^{\mathrm{MA}}$ ) with $0.788<S_{D}<1.0$. Their composition was heterogeneous in regards to both schools (AV, HF, LAE, and MA) and socioeconomic categories (A and $\mathrm{B}$ ).

Cluster 11 78.8-(phenon XVII): $6(8 \%)$ isolates (B4 ${ }^{\mathrm{AV}}, \mathrm{B} 23^{\mathrm{MA}}$, $\mathrm{B} 11^{\mathrm{FE}}, \mathrm{B} 13^{\mathrm{FE}}, \mathrm{B} 16^{\mathrm{FE}}$, and $\mathrm{B} 18^{\mathrm{FMC}}$ ) with $0.788<S_{D}<1.0$. Their composition was heterogeneous and homogeneous in regards to schools (AV, FE, FMC, and MA) and socioeconomic category (B), respectively.

Cluster 12 (78.8-phenon XVIII): $2(2.7 \%)$ isolates $\left(\mathrm{B} 15^{\mathrm{FE}}\right.$ and $\mathrm{C} 4^{\mathrm{AV}}$ ) with $0.788<S_{D}<1.0$. Their composition was heterogeneous in regards to both schools (AV and FE) and socioeconomic categories (B and $\mathrm{C}$ ).

Cluster 13 (78.8-phenon XXX): $2(2.7 \%)$ isolates (D25 $5^{\mathrm{FMC}}$ and $\mathrm{D} 36^{\mathrm{FMC}}$ ) with $0.788<S_{D}<1.0$. Their composition was homogeneous in regards to both school (FMC) and socioeconomic category (D).

Such compositions showed higher similarities among C. albicans strains collected from healthy children classified in identical or different socioeconomic categories. In contrast to these strongly related strains, such behavior was not observed among isolates from healthy children classified in socioeconomic categories A and D, B and D, or C and E. Geographically, some healthy children from identical and different schools also are carriers of highly similar $C$. albicans, but such similarity was not present among other isolates from children from certain schools (i.e. absence of high similarity among isolates from children from schools AV and CS-MEP, CS and AV-FE-HF, FE and CS, FMC and LAE, HF and CS, LAE and FMC-MEP, MA and MEP, MEP and AV-LAE-MA). These data may reflect a restricted dissemination route of such microorganisms in certain population groups in terms of its socioeconomic categories and geographic site (Fig. 3).
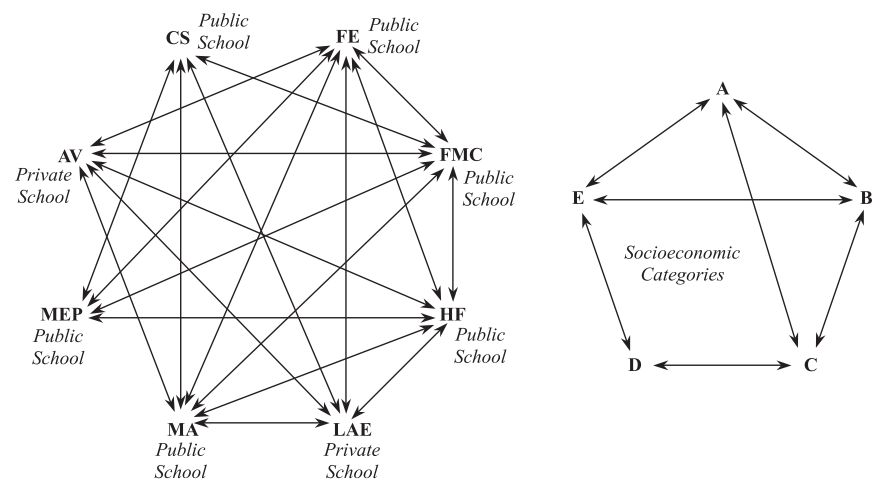

Fig. 3 - A possible dissemination route of C. albicans oral strains from healthy students, based on group compositions generated by UPGMA dendrogram analysis.

A total of $23(30.6 \%)$ isolates $\left(\mathrm{C} 44^{\mathrm{HF}}, \mathrm{D} 21^{\mathrm{CS}}, \mathrm{D} 20^{\mathrm{MEP}}, \mathrm{E} 57^{\mathrm{FMC}}, \mathrm{B} 32^{\mathrm{Av}}\right.$, $\mathrm{A} 33^{\mathrm{LAE}}, \mathrm{A} 52^{\mathrm{LAE}}, \mathrm{E} 30^{\mathrm{CS}}, \mathrm{A} 17^{\mathrm{MA}}, \mathrm{A} 20^{\mathrm{AV}}, \mathrm{A} 40^{\mathrm{LAE}}, \mathrm{A} 48^{\mathrm{LAE}}, \mathrm{A} 23^{\mathrm{LAE}}, \mathrm{B} 38^{\mathrm{LAE}}$, $\mathrm{B} 46^{\mathrm{MA}}, \mathrm{C} 9^{\mathrm{FMC}}, \mathrm{B} 56^{\mathrm{MA}}, \mathrm{D} 28^{\mathrm{FMC}}, \mathrm{C} 16^{\mathrm{HF}}, \mathrm{D} 23^{\mathrm{CS}}, \mathrm{D} 32^{\mathrm{FMC}}, \mathrm{A} 64^{\mathrm{LAE}}$, and $\mathrm{C} 12^{\mathrm{HF}}$ ) showed similar values of $0.499^{49.9 \%} \leq S_{D}<0.788^{78.8 \%}$. These results suggest a higher protein polymorphism degree among some $C$. albicans strains from the socioeconomic categories A ( $8^{42.1 \%} / 19$ isolates $)$ and $\mathrm{D}\left(5^{41.7 \%} /\right.$ 12 isolates), followed by $\mathrm{C}\left(4^{26.7 \%} / 15\right.$ isolates $), \mathrm{B}$ (423.5\% $/ 17$ isolates), and $\mathrm{E}\left(2^{16.7 \%} / 12\right.$ isolates $)$ categories. The same behavior was also detected between the $\operatorname{LAE}\left(7^{63.6 \%} / 11\right.$ isolates) and MA ( $3^{50 \%} / 6$ isolates), followed by $\operatorname{CS}\left(3^{33.3 \%} / 9\right.$ isolates $), \mathrm{AV}\left(2^{33.3 \%} / 6\right.$ isolates $), \mathrm{HF}$ ( $3^{30 \%} / 10$ isolates $)$, FMC ( $4^{25 \%} / 16$ isolates), and MEP ( $1^{14.3 \%} / 7$ isolates) schools.

\section{DISCUSSION}

The analysis of the electrophoretic protein profiles combining computer-statistics program enabled the identification, classification, and even the reclassification of numerous strains, species and genera of bacteria and yeasts in taxonomic and epidemiological studies ${ }^{11,20,23,28,39,57,58,59}$. In the present investigation, seventy-five $C$. albicans strains isolated from the oral cavities of healthy students, according to their socioeconomic categories and/or schools, were analyzed by SDS-PAGE and numerical analysis.

The reproducibility of electrophoretic protein profiles on different slab gels, by the inclusion of molecular weight markers and $C$. albicans CBS562 protein extract, gave the mean value of $S_{D}=0.897$ in agreement with the minimum acceptable value obtained in previous studies ${ }^{50}$. The 
electrophoregrams of C. albicans strains (Fig. 1) showed several protein profiles within a range of molecular weights varying between $18.4 \mathrm{kDa}$ and $66 \mathrm{kDa}$, showing relative similarity when visually compared. The protein electrophoretic fingerprinting showed that protein bands greater than $45 \mathrm{kDa}$ are repeated in the majority of Candida species, suggesting that it may be representative of the genus ${ }^{40,58,59}$. In an attempt to find a region of the lanes with a number of bands great enough to be able to provide an interpretation in terms of intraspecific polymorphism, the protein bands between $18.8 \mathrm{kDa}$ and $66 \mathrm{kDa}$ were analyzed. Such procedure was suggestive enough to express this variability making it possible to determinate several polymorphism degrees or similarities $\left(0.788^{78.8 \%}<S_{D} \leq 1.0^{100 \%}\right)$ among the isolates. During numerical analysis, the confidence interval of \pm 1.25 was used to build a binary matrix, followed by their treatment with the Dice similarity coefficient in order to have a similarity matrix $\left(S_{D}\right)$. Such criterion allowed the maximization of minimal similarity values in dendrograms, with emphasis on the numerical analysis and protein fingerprinting of yeasts ${ }^{5,17}$. In order to ensure whether or not the UPGMA algorithm assess resemblance between two OTUs in the dendrogram construction, the Pearson product-moment correlation coefficient $\left(r_{C S}\right)$ was computed among the elements $S_{\mathrm{ij}}$ (similarity matrix $S_{D}$ ) and $C_{\mathrm{jk}}$ (cophenetic matrix $S_{C}$ ) derived from the dendrogram. It is a measure of the agreement between similarity values present in the dendrogram and those of the matrix $S_{D}{ }^{16,23,26,51,53,54}$. This coefficient showed a value of $r_{C S}=0.8784$ ranging between 0.6 and $0.95^{51,54}$, according to the findings of FARRIS (1969) who pointed out that UPGMA algorithm always maximizes the $r_{C S}$ values. Drawing a vertical line across the dendrogram at a similarity value of $0.7880^{78.8 \%}$ (average similarity), 36 phenons (36 78.8-phenons) were detected. The average similarity value has been employed in several epidemiological studies of Candida species using proteins and DNA fingerprinting techniques associated to numerical analysis, allowing better discriminatory power during analysis of the compositions phenons (clusters) and their relationships ${ }^{19,36,37,39,40}$. Besides, this the vertical line that crosses the dendrogram arbitrarily (i.e. $0.7,0.8,0.9$ ) does not correspond to criteria for the establishment of different taxonomic and epidemiological positions ${ }^{52}$.

A total of 13 major phenons (clusters) were evaluated, according to their homogeneous (identical socioeconomic category and/or school) and heterogeneous (distinct socioeconomic categories and/or schools) characteristics in order to identify $C$. albicans subspecies and their similarities in healthy infantile populations and to establish their possible dissemination routes. Regarding social epidemiological aspects, the composition of the clusters showed higher similarities $\left(0.788^{78.8 \%}<S_{D} \leq\right.$ $1.0^{100 \%}$ ) among some $C$. albicans strains isolated from healthy children independent of their socioeconomic strata (high, medium, or low). Interestingly, similar higher isolates were not found in oral cavities from healthy children from social stratum A and D, B and D, or C and E. This may be explained by the absence of a dissemination route among the children of those strata. According to MOREIRA et al. (2001) the prevalence of $C$. albicans and other Candida species is not determined by social factors. Nevertheless, the lack of research on the prevalence of such species in different social strata in our country limits further speculations concerning this matter ${ }^{33}$. Geographically, some healthy children from identical and different schools (private and public) also are carriers of $C$. albicans highly similar, but such similarity was not found among other isolates from children from certain schools (i.e. absence of higher similarity among isolates from children from schools
$\mathrm{AV}$ and CS-MEP, CS and AV-FE-HF, FE and CS, FMC and LAE, HF and CS, LAE and FMC-MEP, MA and MEP, MEP and AV-LAE-MA). These data also may reflect a restricted dissemination route of $C$. albicans oral strains in certain population groups of healthy students, occurring because of either socioeconomic categories and geographic sites of each child (Fig. 3). Common and frequent mechanisms involved in the diversity of Candida species could explain this similarity. These include chromosomal rearrangements, chromosomal alterations, and complex and unknown gene regulations $\mathrm{s}^{41,42}$. Moreover, tandemly repetitive sequences and telomeric and subtelomeric sequences have been described previously, and it has been postulated that these sequences may be involved in chromosome organization and rearrangements ${ }^{10,43}$. Furthermore, these $C$. albicans strains could be derived from a unique strain as a consequence of the loss of one allele by recombinations or chromosomal rearrangements sensu lato ${ }^{38}$. In contrast to higher similarity, the lower similarity or higher polymorphism degree $\left(0.499^{49.9 \%} \leq S_{D}<\right.$ $\left.0.788^{78.8 \%}\right)$ of the protein profiles was shown in $23(30.6 \%)$ C. albicans oral isolates. Of these, regarding social epidemiological aspects, $42.1 \%$, $41.7 \%, 26.6 \%, 23.5 \%$, and $16.7 \%$ were isolates from children of socioeconomic categories A (8/19 isolates), D (5/12 isolates), C (4/15 isolates), B (4/17 isolates), and E (2/12 isolates), respectively, and geographical categories, 63.6\%, 50\%, 33.3\%, 33.3\%, 30\%, 25\%, and $14.3 \%$ were isolates from children from schools LAE (7/11 isolates), MA (3/6 isolates), CS (3/9 isolates), AV (2/6 isolates), HF (3/10 isolates), FMC (4/16 isolates), and MEP (1/7 isolates), respectively. These results suggest a higher protein polymorphism degree among some $C$. albicans strains from healthy children, independent of their socioeconomic strata or geographic sites. Recently, multilocus enzyme electrophoresis analysis showed that healthy children could harbor just one or more genetic subtypes $^{29}$, as well as immunocompromised patients with predominance of one strain, which could result from intraspecies competition ${ }^{38}$. MATEE et al. (1996) showed the predominance of several C. albicans biotypes in African infant populations, suggesting an inexistent correlation between biotypes and exogenous factors (i.e. age, nutrition, and gender) ${ }^{30}$. Southern Blot hybridization analysis with $\mathrm{Ca} 3$ probe showed a higher genetic similarity among $C$. albicans clinical strains collected from patients independent of their geographic regions ${ }^{46}$ according to our results. Research, employing isoenzyme and DNA fingerprinting analysis (MLEE, RAPD, RFLP using hybridization with $\mathrm{Ca} 3$ and CARE2 probes) also showed strictly related $C$. albicans clinical strains (i.e. sexual pairs, different anatomical sites of the same individual, and phenotypic variants of the same isolate) and some non-related isolates (i.e. different geographic regions, immunocompromised and immunocompetent nonrelated individuals) clustered in phenons with similarity of $S_{\mathrm{AB}} \geq 0.94^{36}$. The higher and lower similarity among $C$. albicans strains may be explained by the relationship and non-relationship or existent and nonexistent dissemination routes, respectively, among healthy-children groups. In this context, the genetic similarity among C. albicans strains, harvested from women with vulvovaginitis and their male partners ${ }^{47,55}$, as well as the genetic similarity among isolates from family members having the same activities has been reported ${ }^{31}$. Complementary studies involving healthy students and their families, teachers, servants, hygiene and nutritional habits must be done in order to establish specific sources of colonization patterns in population groups of healthy children. In general terms, the whole-cell protein profiles obtained by SDS-PAGE associated with computer-assisted numerical analysis, showed to be an important resource for taxonomic and epidemiological studies of yeasts. 


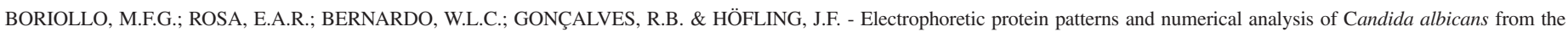
oral cavities of healthy children. Rev. Inst. Med. trop. S. Paulo, 45(5):249-257, 2003.

\section{RESUMO}

\section{Padrões eletroforéticos de proteínas e análise numérica de Candida albicans isoladas da cavidade oral de crianças saudáveis}

O objetivo da presente pesquisa foi avaliar os graus de polimorfismos protéicos entre setenta e cinco linhagens de C. albicans isoladas da cavidade oral de crianças saudáveis provenientes de cinco categorias socioeconômicas e oito escolas (particulares e públicas) do município de Piracicaba, Estado de São Paulo, a fim de identificar subespécies de C. albicans e suas similaridades em grupos de populações infantis e estabelecer suas possíveis rotas de disseminação. Culturas celulares foram desenvolvidas em meio YEPD, coletadas por centrifugação e lavadas com solução salina gelada. As proteínas celulares totais foram extraídas por rompimento celular usando pérolas de vidro e submetidas à técnica de SDS-PAGE. Após a eletroforese, as bandas de proteínas foram coradas com Coomassie-blue e analisadas pelo conjunto de programas estatísticos NTSYS-pc versão 1.70. Matriz de similaridade e dendrograma foram gerados, pela aplicação do coeficiente de similaridade de Dice e do algoritmo UPGMA, respectivamente, os quais permitiram avaliar os graus de polimorfismo ou similaridade intra-específico, baseados nos padrões eletroforéticos de proteínas totais de isolados orais de C. albicans. Um total de 13 principais fenons (grupos) foi analisado de acordo com suas características homogêneas (categoria socioeconômica e/ou escola idênticas) e heterogêneas (categorias socioeconômicas e/ou escolas diferentes). Com relação ao aspecto epidemiológico socioeconômico, as composições dos grupos mostraram alta similaridade $\left(0.788<S_{D} \leq\right.$ 1.0) entre algumas linhagens de $C$. albicans isoladas de crianças saudáveis independentemente de suas camadas socioeconômicas (alta, média e baixa). Isolados de alta similaridade não foram encontrados nas cavidades orais de crianças saudáveis pertencentes às camadas sociais A e D, B e $\mathrm{C}$, ou $\mathrm{C}$ e E. Isto pode ser explicado pela ausência de uma rota de disseminação entre estas crianças. Geograficamente, algumas crianças saudáveis entre escolas idênticas e diferentes (particulares e públicas) também são portadoras de linhagens semelhantes, mas tal similaridade não foi encontrada entre outros de determinadas escolas. Esses dados podem refletir uma rota de disseminação restrita destes microrganismos em alguns grupos de escolares saudáveis, a qual pode ser dependente da categoria socioeconômica ou local geográfico de cada criança. Em contraste à alta similaridade, a baixa similaridade ou alto grau de polimorfismo $\left(0.499 \leq S_{D}<0.788\right)$ dos perfis protéicos foi demonstrado em $23(30,6 \%)$ isolados orais de $C$. albicans. Considerando o aspecto epidemiológico social, $42,1 \%, 41,7 \%, 26,6 \%, 23,5 \%$ e $16,7 \%$ foram isolados de crianças provenientes das categorias socioeconômicas A, D, C, B e E, respectivamente, e geograficamente, $63,6 \%, 50 \%, 33,3 \%$, $33,3 \%, 30 \%, 25 \%$ e $14,3 \%$ foram isolados de crianças provenientes das escolas LAE, MA, CS, AV, HF, FMC e MEP, respectivamente. Tais resultados sugerem um maior grau de polimorfismo entre algumas linhagens isoladas de crianças saudáveis independentemente de suas camadas sociais ou locais geográficos. Estudos complementares envolvendo escolares saudáveis e seus familiares, professores, serventes, hábitos nutricionais e de higiene deverão ser realizados a fim de estabelecer as fontes de tais padrões de colonização em grupos de populações de crianças saudáveis. Os perfis de proteínas totais obtidos por SDS-PAGE associados com análise numérica computadorizada podem proporcionar critérios adicionais para os estudos epidemiológicos e taxonômicos de C. albicans.

\section{ACKNOWLEDGMENTS}

This research work was supported by FAPESP (Proc. 97/13518-3)

\section{REFERENCES}

1. ALFENAS, A.C. - Eletroforese de isoenzimas e proteínas afins; fundamentos e aplicações em plantas e microrganismos. Viçosa, Editora UFV, 1998.

2. AMES, G.F.L. - Resolution of bacterial proteins by polyacrylamide gel electrophoresis on slabs. J. biol. Chem., 249: 634-644, 1974.

3. ANTONSSON, B.; MONTESSUIT, S.; FRIEDLI, L.; PAYTON, M.A. \& PARAVICINI, G. - Protein kinase $\mathrm{C}$ in yeast. Characteristics of the Saccharomyces cerevisiae $\mathrm{PKC} 1$ gene product. J. biol. Chem., 269: 16821-16828, 1994.

4. ASAKURA, K.; IWAGUCHI, S.; HOMMA, M. et al. - Electrophoretic karyotypes of clinically isolated yeasts of Candida albicans and C. glabrata. J. gen. Microbiol., 137: 2531-2538, 1991.

5. BORIOLLO, M.F.G.; ROSA, E.A.R.; ROSA, R.T. \& HÖFLING, J.F. - Criteria for Candida albicans numerical analysis based on electrophoretic protein patterns. Rev. argent. Microbiol., 32: 123-128, 2000.

6. BRADFORD, M.M. - A rapid and sensitive method for the quantitation of microgram quantities of protein utilizing the principle of protein-dye binding. Analyt. Biochem., 72: 248-254, 1976.

7. BRUNEAU, S. \& GUINET, R. - Rapid identification of medically important yeasts by electrophoretic protein patterns. FEMS Microbiol. Lett., 49: 329-333, 1989.

8. CASANOVA, M. \& CHAFFIN, D.W.L. - Cell wall glycoproteins of Candida albicans as released by different methods. J. gen. Microbiol., 137: 1045-1051, 1991.

9. CATO, E.P.; HASH, D.E.; HOLDEMAN, L.V. \& MOORE, W.E.C. - Electrophoretic study of Clostridium species. J. clin. Microbiol., 15: 688-702, 1982.

10. CHIBANA, H.; IWAGUCHI, S.I.; HOMMA, M. et al. - Diversity of tandemly repetitive sequences due to short periodic repetitions in the chromosomes of Candida albicans. J. Bact., 176: 3851-3858, 1994.

11. COSTAS, M.; HOLMES, B. \& SLOSS, L.L. - Numerical analysis of electrophoretic protein patterns of Providencia rustigianii strains from humam diarrhoea and other sources. J. appl. Bact., 63: 319-328, 1987.

12. COSTAS, M.; HOLMES, B.; WOOD, A.C. \& ON, S.L.W. - Numerical analysis of electrophoretic protein patterns of Providencia rettgeri strains from human faeces, urine and other specimens. J. appl. Bact., 67: 441-452, 1989a.

13. COSTAS, M.; SLOSS, L.L.; OWEN, R.J. \& GASTON, M.A. - Evaluation of numerical analysis of SDS-PAGE of protein patterns for typing Enterobacter cloacae. Epidem. Infect., 103: 265-274, 1989b.

14. DICE, L.R. - Measures of the amount of ecologic association between species. Ecology, 26: $297-302,1945$.

15. EZE, J.M.O. \& DUMBROFF, E.B. - A comparison of the Bradford and Lowry methods for the analysis of protein in chlorophyllous tissue. Canad. J. Bot., 60: 1046-1049, 1982.

16. FARRIS, J.S. - On the cophenetic correlation coefficient. System. Zool., 18: 279-285, 1969.

17. GUILLAMON, J.M.; QUEROL, A.; JIMENEZ, M. \& HUERTA, T. - Phylogenetic relationships among wine yeast strains based on electrophoretic whole-cell protein patterns. Int. J. Food. Microbiol., 18: 115-125, 1993. 
18. HALL, R. - Symposium on the use of electrophoresis in the taxonomy of algae and fungi. Electrophoretic protein profiles as criteria in the taxonomy of fungi and algae. Bull. Torrey Bot. Club, 100: 253-259, 1973.

19. HELlSTEIN, J.; VAWTER-HUGART, H.; FOTOS, P.; SCHMID, J. \& SOLL, D.R. Genetic similarity and phenotypic diversity of commensal and pathogenic strains of Candida albicans isolated from the oral cavity. J. clin. Microbiol., 31: 3190-3199, 1993.

20. HÖFLING, J.F.; ROSA, E.A.R.; PEREIRA, C.V.; BORIOLLO, M.F.G. \& RODRIGUES, J.A.O. - Differentiation and numerical analysis of oral yeasts based on SDS-PAGE profiles. Influence of the culture media on the whole-cell protein extracts. Braz. J. Biol., 61: 507-516, 2001.

21. HOLMES, B.; COSTAS, M. \& SLOSS, L.L. - Numerical analysis of SDS-PAGE protein patterns of Serratia marcescens: a comparison with other typing methods. Epidem. Infect., 105: 107-117, 1990.

22. IZARD, D.; FERRAGUT, C.; GAVINI, F. et al. - Klebsiella terrigena, a new species from soil and water. Int. J. syst. Bact., 31: 116-127, 1981.

23. KERSTERS, K. \& DE LEY, J. - Identification and grouping of bacteria by numerical analysis of their electrophoretic protein patterns. J. gen. Microbiol., 87: 333-342, 1975

24. KERSTERS, K. - Numerical methods in the classification of bacteria by protein electrophoresis. In: GOODFELLOW, M.; JONES, D. \& PRIESR, F.G. Computerassisted bacterial systematics. London, Academic Press, 1985. p. 337-368.

25. LAEMMLI, U.K. - Cleavage of structural proteins during the assembly of the head of bacteriophage T4. Nature (Lond.), 227: 680-685, 1970.

26. LEGENDRE, L. \& LEGENDRE, P. - Numerical Ecology. New York, Elsevier, 1983.

27. LEHMANN, P.F.; KEMKER, B.J.; HSIAO, C.B. \& DEV, S. - Isoenzyme biotypes of Candida species. J. clin. Microbiol., 27: 2514-2521, 1989.

28. MAIDEN, M.F.J. \& TANNER, A. - Identification of oral yeasts by polyacrylamide gel electrophoresis. Oral Microbiol. Immunol., 6: 187-190, 1991.

29. MATA, A.L.; ROSA, R.T.; ROSA, E.A.R.; GOLÇALVES, R.B. \& HÖFLING, J.F. Clonal variability among oral Candida albicans assessed by allozyme electrophoresis analysis. Oral Microbiol. Immunol., 15: 350-354, 2000.

30. MATEE, M.I.; SAMARANAYAKE, L.P.; SCHEUTZ, F. et al. - Biotypes of oral Candida albicans isolates in a Tanzanian child population. Acta path. microbiol. scand., 9: 623-628, 1996.

31. MEHTA, S.K.; STEVENS, D.A.; MISHRA, S.K.; FEROZE, F. \& PIERSON, D.L. Distribution of Candida albicans genotypes among family members. Diagn. Microbiol. infect. Dis., 34: 19-25, 1999.

32. MONOD, M.; PORCHET, S.; BAUDRAZ-ROSSELET, F. \& FRENK, E. - The identification of pathogenic yeast strains by electrophoretic analysis of their chromosomes. J. med. Microbiol., 32: 123-129, 1990.

33. MOREIRA, D.; SPOLIDÓRIO, D.M.P.; RODRIGUES, J.A.O. et al. - Candida spp. biotypes in the oral cavity of school children from different socioeconomic categories in Piracicaba - SP, Brazil. Pesq. odont. bras., 15: 187-195, 2001.

34. ODDS, F.C. \& BERNAERTS, R. - CHROMagar Candida, a new differential isolation medium for presumptive identification of clinically important Candida species. J. clin. Microbiol., 32: 1923-1929, 1994.

35. OWEN, R.J. \& JACKMAN, P.J.H. - The similarities between Pseudomonas paucimobilis and allied bacteria derived from analysis of deoxyribonucleic acids and electrophoretic protein patterns. J. gen. Microbiol., 128: 2945-2954, 1982.
36. PUJOL, C.; JOLY, S.; LOCKHART, S.R. et al. - Parity among the randomly amplified polymorphic DNA method, multilocus enzyme electrophoresis, and Southern blot hybridization with the moderately repetitive DNA probe $\mathrm{Ca} 3$ for fingerprinting Candida albicans. J. clin. Microbiol., 35: 2348-2358, 1997.

37. PUJOL, C.; RENAUD, F.; MALliE, M.; DE MEEUS, T. \& BASTIDE, J.M. - Atypical strains of Candida albicans recovered from AIDS patients. J. med. vet. Mycol., 35: 115-121, 1997.

38. REYNES, J.; PUJOL, C.; MOREAU, C. et al. - Simultaneous carriage of Candida albicans strains from HIV-infected patients with oral candidiasis: multilocus enzyme electrophoresis analysis. FEMS Microbiol. Lett., 137: 269-273, 1996.

39. ROSA, E.A.R.; PEREIRA, C.V.; ROSA, R.T. \& HÖFLING, J.F. - Evaluation of different dehydrogenases to recognize Candida species commonly isolated from human oral cavities. Rev. argent. Microbiol., 31: 165-172, 1999.

40. ROSA, E.A.R.; ROSA, R.T.; PEREIRA, C.V.; BORIOLLO, M.F.G. \& HÖFLING, J.F. Analysis of parity between protein-based electrophoretic methods for the characterization of oral Candida species. Mem. Inst. Oswaldo Cruz, 95: 801-806, 2000 .

41. RUSTCHENKO, E.P.; HOWARD, D.H. \& SHERMAN, F. - Chromosomal alterations of Candida albicans are associated with the gain and loss of assimilating functions. J. Bact., 176: 3231-3241, 1994.

42. RUSTCHENKO-BULGAC, E.P.; SHERMAN, F. \& HICKS, J.B. - Chromosomal rearrangements associated with morphological mutants provide a means for genetic variation of Candida albicans. J. Bact., 172: 1276-1283, 1990.

43. SADHU, C.; McEACHERN, M.J.; RUSTCHENKO-BULGAC, E.P. et al. - Telomeric and dispersed repeat sequences in Candida yeasts and their use in strain identification. J. Bact., 173: 842-850, 1991.

44. SANDVEN, P. - Laboratory identification and sensitivity testing of yeast isolates. Acta odont. scand., 48: 27-36, 1990.

45. SCHERER, S. \& STEVENS, D.A. - Application of DNA typing methods to epidemiology and taxonomy of Candida species. J. clin. Microbiol., 25: 675-679, 1987.

46. SCHMID, J.; HERD, S.; HUNTER, P.R. et al. - Evidence for a general-purpose genotype in Candida albicans, highly prevalent in multiple geographical regions, patient types and types of infection. Microbiology, 145: 2405-2413, 1999.

47. SCHMID, J.; VOSS, E. \& SOLL, D.R. - Computer-assisted methods for assessing strain relatedness in Candida albicans by fingerprinting with the moderately repetitive sequence Ca3. J. clin. Microbiol., 29: 1236-1243, 1990.

48. SHECHTER, Y. - Symposium on the use of electrophoresis in the taxonomy of algae and fungi. IV. Electrophoresis and taxonomy of medically important fungi. Bull. Torrey Bot. Club, 100: 277-287, 1973.

49. SHEN, H.D.; CHOO, K.B.; TSAI, W.C. et al. - Differential identification of Candida species and other yeasts by analysis of [35S] methionine-labeled polypeptide profiles. Analyt. Biochem., 175: 548-551, 1988.

50. SNEATH, P.H. \& JOHNSON, R. - The influence on numerical taxonomic similarities of errors in microbiological tests. J. gen. Microbiol., 72: 377-392, 1972.

51. SNEATH, P.H.A. \& SOKAL, R.Q. - Numerical taxonomy. San Francisco, Freeman, 1973.

52. SNEATH, P.H.A. - Bacterial classification. II. Numerical taxonomy. In: STALEY, J.T.; BRYANT, M.P.; PFENNIG, N. \& HOLT, J.G. Bergey's manual of systematic bacteriology. Baltimore, Williams and Wilkins, 1989. v. 3, p. 1619-1623.

53. SOKAL, R.R. \& ROHLF, F.J. - The comparison of dendrograms by objective methods. Taxon, 11: 33-40, 1962. 
BORIOLLO, M.F.G.; ROSA, E.A.R.; BERNARDO, W.L.C.; GONÇALVES, R.B. \& HÖFLING, J.F. - Electrophoretic protein patterns and numerical analysis of Candida albicans from the oral cavities of healthy children. Rev. Inst. Med. trop. S. Paulo, 45(5):249-257, 2003.

54. SOKAL, R.R. \& ROHLF, F.J. - The intelligent ignoramus, an experiment in numerical taxonomy. Taxon, 19: 305-309, 1970.

55. STEVENS, D.A.; ODDS, F.C. \& SCHERER, S. - Application of DNA typing methods to Candida albicans epidemiology and correlations with phenotype. Rev. infect. Dis., 12: 258-266, 1990.

56. STUDIER, F.W. - Analysis of bacteriophage T7 early RNAs and proteins on slabs gels. J. molec. Biol., 79: 237-248, 1973.

57. TANNER, A.C.R.; LISTGARTEN, M.A.; EBERSOLE, J.L. \& STRZEMPKO, M.N. Bacteroides forsythus sp. nov., a slow growing, fusiform Bacteroides sp. from the human oral cavity. Int. J. syst. Bact., 36: 213-221, 1986.

58. VANCANNEYT, M.; LERBERGE, E.V.; BERNY, J.F.; HENNEBERT, G.L. \& KERSTERS, K. - The application of whole-cell protein electrophoresis for the classification and identification of basidiomycetous yeast species. Antonie v. Leeuwenhoek, 61: 69-78, 1992.
59. VANCANNEYT, M.; POT, B.; HENNEBERT, G. \& KERSTERS, K. - Differentiation of yeast species based on electrophoretic whole-cell protein patterns. Syst. appl. Microbiol., 14: 23-32, 1991.

60. WATERS, M.G. \& BLOBEL, G. - Secretory protein translocation in a yeast cell-free system can occur posttranslationally and requires ATP hydrolysis. J. Cell Biol., 102: 1543-1550, 1986.

61. WOONTNER, M. \& JAEHNING, J.A. - Accurate initiation by RNA polimerase II in a whole cell extract from Saccharomyces cerevisiae. J. biol. Chem., 265: 8979-8982, 1990.

Received: 24 Februarry 2003

Accepted: 17 September 2003 